\title{
STIM1 at the plasma membrane as a new target in progressive chronic lymphocytic leukemia
}

Marjolaine Debant ${ }^{1}$, Miguel Burgos ${ }^{1}$, Patrice Hemon ${ }^{1}$, Paul Buscaglia' ${ }^{1}$, Tinhinane Fali', Sarra Melayah ${ }^{1,4}$, Nelig Le Goux' ${ }^{1}$, Christophe Vandier ${ }^{2,3}$, Marie Potier-Cartereau, ${ }^{2,3}$, Jacques-Olivier Pers ${ }^{1}$, Adrian Tempescul ${ }^{1,5}$, Christian Berthou ${ }^{1,5}$, Cristina Bagacean ${ }^{1,4,5}$, Olivier Mignen ${ }^{1,3 \dagger}$ and Yves Renaudineau ${ }^{1,3,4^{*}+}$ (D)

\begin{abstract}
Background: Dysregulation in calcium $\left(\mathrm{Ca}^{2+}\right)$ signaling is a hallmark of chronic lymphocytic leukemia (CLL). While the role of the $\mathrm{B}$ cell receptor $(\mathrm{BCR}) \mathrm{Ca}^{2+}$ pathway has been associated with disease progression, the importance of the newly described constitutive $\mathrm{Ca}^{2+}$ entry (CE) pathway is less clear. In addition, we hypothesized that these differences reflect modifications of the CE pathway and $\mathrm{Ca}^{2+}$ actors such as Orai1, transient receptor potential canonical (TRPC) 1, and stromal interaction molecule 1 (STIM1), the latter being the focus of this study.

Methods: An extensive analysis of the $\mathrm{Ca}^{2+}$ entry (CE) pathway in CLL B cells was performed including constitutive $\mathrm{Ca}^{2+}$ entry, basal $\mathrm{Ca}^{2+}$ levels, and store operated $\mathrm{Ca}^{2+}$ entry (SOCE) activated following B cell receptor engagement or using Thapsigargin. The molecular characterization of the calcium channels Orai1 and TRPC1 and to their partner STIM1 was performed by flow cytometry and/or Western blotting. Specific siRNAs for Orai1, TRPC1 and STIM1 plus the Orai1 channel blocker Synta66 were used. CLL B cell viability was tested in the presence of an anti-STIM1 monoclonal antibody (mAb, clone GOK) coupled or not with an anti-CD20 mAb, rituximab. The Cox regression model was used to determine the optimal threshold and to stratify patients.

Results: Seeking to explore the CE pathway, we found in untreated CLL patients that an abnormal CE pathway was (i) highly associated with the disease outcome; (ii) positively correlated with basal $\mathrm{Ca}^{2+}$ concentrations; (iii) independent from the BCR-PLCY2-InSP ${ }_{3} R$ (SOCE) $\mathrm{Ca}^{2+}$ signaling pathway; (iv) supported by Orai1 and TRPC1 channels; (v) regulated by the pool of STIM1 located in the plasma membrane (STIM1PM); and (vi) blocked when using a mAb targeting STIM1 $1_{\mathrm{PM}}$. Next, we further established an association between an elevated expression of STIM1PM and clinical outcome. In addition, combining an anti-STIM1 mAb with rituximab significantly reduced in vitro CLL B cell viability within the high STIM1 $1_{P M}$ CLL subgroup.

Conclusions: These data establish the critical role of a newly discovered $B C R$ independent $\mathrm{Ca}^{2+}$ entry in CLL evolution, provide new insights into CLL pathophysiology, and support innovative therapeutic perspectives such as targeting STIM1 located at the plasma membrane.
\end{abstract}

Keywords: CLL, STIM1, Constitutive $\mathrm{Ca}^{2+}$ entry, Disease outcome

\footnotetext{
* Correspondence: yves.renaudineau@univ-brest.fr

${ }^{+}$Olivier Mignen and Yves Renaudineau contributed equally as senior authors

${ }^{1}$ INSERM U1227 B lymphocytes and autoimmunity, University of Brest, Brest,

France

${ }^{3}$ IC-CGO network from "Canceropole Grand Ouest", Brest, France

Full list of author information is available at the end of the article
}

(c) The Author(s). 2019 Open Access This article is distributed under the terms of the Creative Commons Attribution 4.0 International License (http://creativecommons.org/licenses/by/4.0/), which permits unrestricted use, distribution, and reproduction in any medium, provided you give appropriate credit to the original author(s) and the source, provide a link to the Creative Commons license, and indicate if changes were made. The Creative Commons Public Domain Dedication waiver (http://creativecommons.org/publicdomain/zero/1.0/) applies to the data made available in this article, unless otherwise stated. 


\section{Background}

Chronic lymphocytic leukemia (CLL) is characterized by a heterogeneous natural history that is partly predicted by clinical, epigenetic and genetic features [1]. In addition, there is long standing evidence that CLL B cells (B-CLL) present an altered calcium $\left(\mathrm{Ca}^{2+}\right)$ signaling pathway, which evolves with disease progression $[2,3]$. Induction of the $\mathrm{Ca}^{2+}$ signaling pathway in $\mathrm{B}$ cells is thought to follow the model in which BCR interaction with the antigen results in the formation of the signalosome consisting of an active complex composed of spleen tyrosine kinase (Syk), B-cell linker protein (BLNK), Bruton-tyrosine-kinase (BTK), phospholipase C gamma 2 (PLCY2), and phosphatidylinositol-4,5-bisphosphate 3-kinase $\delta$ (PI3K $\delta$ ) (Additional file 1: Figure S1A). Signalosome activation cleaves the membrane phospholipid phosphatidyl inositol 4.5-biphosphate (InsP2) into diacylglycerol (DAG) and inositol 1,4,5triphosphate (InsP3), which subsequently, through binding to the endoplasmic reticulum (ER) IP3 receptor ( $\left.\mathrm{InsP}_{3} \mathrm{R}\right)$, mobilizes initially $\mathrm{Ca}^{2+}$ from stores and secondarily extracellular $\mathrm{Ca}^{2+}$ [4]. The reticular stromal interaction molecule 1 (STIM1) and plasma-membrane Orail channel are believed to be the main molecular actors of store operated $\mathrm{Ca}^{2+}$ entry (SOCE) in lymphocytes [5-8]. Finally, an increase in $\mathrm{Ca}^{2+}$ entry following $B$ cell receptor $(B C R)$ engagement leads to cellular metabolic changes, cell survival, proliferation, differentiation, migration, antibody production and, at very high concentrations, apoptosis [9-12].

At first glance, CLL cases with indolent and stable disease present $\mathrm{B}$ cells that are ineffective at mobilizing $\mathrm{Ca}^{2}$ + after BCR cross-linking, thus resembling B cells anergized in vivo after chronic antigenic stimulation [13]. For these patients, B-CLL cell incapacity to mobilize $\mathrm{Ca}^{2}$ ${ }^{+}$was related to mutated $\operatorname{IgHV}$ patients, a reduced level of cell surface (s) IgM, and a defective signalosome. In contrast, CLL cases with a worse clinical outcome show an elevated basal $\mathrm{Ca}^{2+}$ level that can be enhanced upon sIgM triggering. The elevated $\mathrm{Ca}^{2+}$ signaling in the CLL group with progressive disease was associated with an unmutated $\operatorname{IgHV}$ status and an elevated level of CD38, but was not linked to any specific cytogenetic markers [14]. However, other processes are described in order to provide alternative explanations for $\mathrm{Ca}^{2+}$ dysregulation in B-CLL cells such as a BCR autonomous signaling capacity due to an internal epitope present in the second framework of stereotyped $I g H V$ that can be abrogated by using a BCR signaling inhibitor [15], an incapacity of the ER to release $\mathrm{Ca}^{2+}$ due to an inhibitory interaction between Bcl-2 (overexpressed in B-CLL cells) and the endoplasmic $\operatorname{Ins}_{3} \mathrm{R}$ [16], and last but not least an incompletely characterized $\mathrm{BCR}$ independent $\mathrm{Ca}^{2+}$ pathway recently described in B-CLL cells $[17,18] . \mathrm{Ca}^{2+}$ deregulations in B-CLL cells and their correlation with disease evolution and severity are far from being fully understood. Reversing specific changes in deregulated $\mathrm{Ca}^{2+}$ fluxes may also represent new therapeutic opportunities to answer unmet needs in CLL treatment.

In this study we deciphered $\mathrm{Ca}^{2+}$ entry deregulation in B-CLL cells and tested whether BCR-dependent or BCR-independent $\mathrm{Ca}^{2+}$ entry would be relevant in CLL outcome. The latter was critical for disease progression, and we therefore analyzed and characterized a novel $\mathrm{Ca}^{2}$ + signaling pathway, referred to as constitutive $\mathrm{Ca}^{2+}$ entry (CE), which is triggered by STIM1 located at the plasma-membrane $\left(\mathrm{STIM} 1_{\mathrm{PM}}\right)$. Interestingly, we demonstrated that blocking CE with an anti-STIM1 monoclonal antibody $(\mathrm{mAb})$ presents innovative therapeutic perspectives in CLL.

\section{Materials and methods CLL population}

Clinical information was retrospectively obtained from 74 untreated patients diagnosed with CLL according to the World Health Organization (WHO) classification [19], and 13 healthy volunteers at the Brest University Hospital. Disease assessment included Binet stage determination, progression free survival (PFS), treatment free survival (TFS), CD38 expression, lymphocyte counts, lymphocyte doubling time (LDT), cytogenetic risk-status, and $\operatorname{IgHV}$ mutational status, which were performed as previously described [20]. Consent was obtained from all individuals and the protocol approved by the Ethical Board at the Brest University Hospital (clinicaltrials: NCT03294980; cohort OFICE; CRB Biobank collection 2008-2014), in accordance with the Declaration of Helsinki.

\section{Sample preparation and flow cytometry}

Peripheral blood mononuclear cells (PBMC) were isolated from whole blood by Ficoll-Hypaque density gradient centrifugation (Eurobio, Courtaboeuf, France) and B cells were further enriched using the Pan B-cell Isolation Kit (Miltenyi Biotec GmbH, Bergisch Gladbach, Germany). Cell purity was assessed by fluorescence-activated cell sorting (FACS) analysis and was over $95 \%$ for B cells (CD19+).

All monoclonal antibodies (mAb) were from BeckmanCoulter (Brea, CA, USA) unless specified: FITC-conjugated anti-IgM (clone: SA-D4), cyanin (Cy)5.5-conjugated anti-CD38 (LS198.4.3), electron coupled dye (ECD)-labelled anti-CD5 (BL1a), allophycocyanin (APC)-conjugated anti-IgD (1A6-2, BD Biosciences, Franklin-Lakes, NJ), APC-Alexa Fluor 700 (AF700)-conjugated anti-CD19 (J4-119), Pacific blue (PB)-conjugated anti-CD21 (1A4CD27) mAbs with saturating concentrations were incubated for $10 \mathrm{~min}$ at RT with $10 \mu \mathrm{l}$ of PBS-washed blood. Versalyse solution (Beckman- Coulter) was added for $10 \mathrm{~min}$ in order to lyse red blood cells. The 
determination of the mean fluorescence intensity (MFI) of all markers required a minimum of 5000 events. The results were standardized to those obtained with isotype controls. Data were analysed using Kaluza 1.5 software (Beckman-Coulter).

For intracellular staining, preliminary fixation and permeabilization were performed with the cytofix/cytoperm kit (BD Biosciences) followed by a $30 \mathrm{~min}$ incubation at $4{ }^{\circ} \mathrm{C}$ with Phyco-Erythrin (PE)-conjugated anti-STIM1 (Gok, BD Biosciences), PC7-conjugated antiCD19 and APC-AF700-conjugated anti-CD5 mAbs. The same protocol was applied for plasma membrane STIM1 $1_{\mathrm{PM}}$ with the omission of the permeabilization step. In the transfection experiments a polyclonal rabbit anti-human Orail Ab (Sigma-Aldrich, Saint-Louis, MO) or anti-TRPC1 Ab (Alomone, Jerusalem, Israel) were used after the permeabilization step, and mAb staining was assessed with a FITC-conjugated goat anti-rabbit IgG (Jackson Immunoresearch, Ely, UK). To assess PLC 2 phosphorylation, $5 \times 10^{5}$ cells were fixed and permeabilized with cold $80 \%$ methanol solution during $30 \mathrm{~min}$. After 2 washes in PBS-BSA 0.05\%, APC-conjugated anti-pPLC 2 mAb (clone K86-689.37, BD Biosciences) was added.

\section{Effect on cell viability}

For each patient, B-CLL cells were incubated $48 \mathrm{~h}$ in 24-well plates at $37^{\circ} \mathrm{C}$ with either (i) $10 \mu \mathrm{g} / \mathrm{ml}$ murine IgG2a (Biolegend, San-Diego, CA) (ii) $10 \mu \mathrm{g} / \mathrm{ml}$ anti-STIM1 (Gok), (iii) $10 \mu \mathrm{g} / \mathrm{ml}$ RTX (Roche, Paris, France), or (iv) $2 \times 10 \mu \mathrm{g} / \mathrm{ml}$ anti-STIM1 + RTX. All cultures were set at $5 \times 10^{5} \mathrm{~B}$ cells $/ \mathrm{mL}$ in RPMI-1640 (Sigma-Aldrich) supplemented with $2 \mathrm{mML}$-glutamine, antibiotics, and $20 \%$ of decomplemented normal human serum AB (Invitrogen, Carlsbad, CA). B cells were recovered, washed and stained for $15 \mathrm{~min}$ with FITC-conjugated annexin-V (AV) / propidium iodide (PI) and AF700-conjugated anti-CD19 antibody according to the Beckman-Coulter apoptosis kit protocol. The decrease in the percentage of live cells $\left(\mathrm{CD} 19^{+}\right.$AV-PI- $)$was recorded.

\section{Calcium entry recording}

For CE measurements, B cells were loaded with $2 \mu \mathrm{M}$ Fura-2/AM dye (Molecular Probes, Leiden, Netherlands) and $2 \mu \mathrm{M}$ Pluronic acid (Gibco, Waltham, MA) for 30 min at $37^{\circ} \mathrm{C}$ in a medium containing: $135 \mathrm{mM} \mathrm{NaCl}, 5$ $\mathrm{mM} \mathrm{KCl}, 1 \mathrm{mM} \mathrm{MgCl}_{2}, 10 \mathrm{mM}$ HEPES, $10 \mathrm{mM}$ Glucose with an 7,4-adjusted pH (Buffer A) supplemented with 5 $\mathrm{mM} \mathrm{CaCl}{ }_{2}$. Cells were washed and left to attach in the same buffer on $12 \mathrm{~mm}$ Cell-Tak (Corning, NY) precoated coverslides for $20 \mathrm{~min}$, allowing the de-esterification of the dye. Fura-2 was excited alternatively at 340 and $380 \mathrm{~nm}$ (Polychrome V, TILL photonics), and fluorescence emission was recorded at $510 \mathrm{~nm}$ using a fluorescence microscope (IX71, Olympus) equipped with a dichroic mirror (415DCLP) and a 14-bit CCD camera (ExiBlue, Qimaging). After the stabilization of basal fluorescence, the extracellular medium was replaced with Buffer A supplemented with $0.5 \mathrm{mM} \mathrm{CaCl} 2$ for $100 \mathrm{~s}$ and again with the original $5 \mathrm{mM} \mathrm{CaCl} \mathrm{Cl}_{2}$-containing Buffer A after curve stabilization. Excitation/emission ratio $\left(\mathrm{F}_{340 \mathrm{~nm}} / \mathrm{F}_{380 \mathrm{~nm}}\right)$ was calculated for each time point and each cell with the Metafluor 6.3 Software (Universal Imaging, West Chester, USA). The amplitude of $\mathrm{CE}$ was calculated after normalization to the basal ratio $\left(\Delta \mathrm{F} / \mathrm{F}_{0}\right)$, as the difference between average values of basal ratio measured in $5 \mathrm{mM}$ external $\mathrm{Ca}^{2+}$ and the average ratio value in $0.5 \mathrm{mM} \mathrm{Ca}^{2+}$.

For anti-IgM and Thapsigargin (TG)-induced calcium entry, B cells were loaded in Buffer A containing $1.8 \mathrm{mM}$ $\mathrm{CaCl}_{2}$ and $2 \mu \mathrm{M}$ Fura-2/AM (Fura-2 QBT Kit, Molecular Devices) for $1 \mathrm{~h}$ at $37^{\circ} \mathrm{C}$ in Cell-Tak precoated 96-well plates, and fluorescence acquisition (excitation 340 and $380 \mathrm{~nm}$; emission $510 \mathrm{~nm}$ ) was performed on the Flexstation 3 microplate reader with SoftMax Pro 5.4.5 software (Molecular Devices, San Josa, CA). For anti-IgM induced $\mathrm{Ca}^{2+}$ response, the extracellular medium was replaced with Buffer A supplemented with $10 \mathrm{mM} \mathrm{CaCl}$, before reading, and $10 \mu \mathrm{M}$ of polyclonal goat anti-human IgM (Jackson Immunoresearch) were injected after $150 \mathrm{~s}$. TG-induced ER $\mathrm{Ca}^{2+}$ release, extracellular medium was replaced with Buffer A supplemented with $100 \mu \mathrm{M}$ EGTA just before starting the reading protocol. A stimulation with $2 \mu \mathrm{M}$ of TG was performed after 100 $\mathrm{s}$ of recording, and $1.8 \mathrm{mM} \mathrm{CaCl}_{2}$ was added after $700 \mathrm{~s}$ in order to quantify SOCE entry. $\mathrm{Ca}^{2+}$ entry were quantified after value normalization $\left(\Delta \mathrm{F} / \mathrm{F}_{0}\right)$ with the exception of basal $\mathrm{Ca}^{2+}$ concentrations estimated as the average of initial $\mathrm{F}_{340 \mathrm{~nm}} / \mathrm{F}_{380 \mathrm{~nm}}$ values.

In selected experiments, $1 \mu \mathrm{M}$ Ibrutinib (SelleckChem, Munich, Germany), $5 \mu \mathrm{M}$ LY294002 (Sigma Aldrich), $2.5 \mu \mathrm{M}$ Synta66 (Sigma Aldrich), DMSO, $10 \mu \mathrm{g} / \mathrm{ml}$ anti-STIM1 (clone GOK) or $10 \mu \mathrm{g} / \mathrm{ml}$ IgG2a mAb were added to the loading buffer.

\section{Transient transfection}

The small interfering RNAs (siRNA) targeting Orai1 (GCAACGUGCACAAUCUCAAtt, Sigma), STIM1 (AGG UGGAGGUGCAAUAUUAtt, Dharmacon, Lafayette, CO), TRPC1 (s7311), and the control siRNA (4390843) were purchased from Ambion unless specified and transfected in B-CLL cells from $3 \mathrm{CE}+$ CLL patients by nucleofection (Lonza, Basel, Switzerland) as previously described [17, 21]. After a 48 h-incubation, the knock-down was controlled by flow cytometry and intracellular $\mathrm{Ca}^{2+}$ analysis was performed. 


\section{Western blot}

Protein extraction was performed by incubating $10^{7} \mathrm{~B}$ cells for $30 \mathrm{~min}$ on ice in a lysis buffer containing: 20 $\mathrm{mM}$ Tris $\mathrm{HCl} \mathrm{pH7.5,} 150 \mathrm{mM} \mathrm{NaCl}, 1 \mathrm{mM}$ EDTA, 1 mM EGTA, 1\% Triton X100, $2.5 \mathrm{mM} \mathrm{Na}^{+}$pyrosodium tetraphosphate, $1 \mathrm{mM}$ glycerophosphate, $1 \mathrm{mM} \mathrm{Na}{ }^{+}$ orthovanadate, $1 \mu \mathrm{g} / \mathrm{ml}$ leupeptin and protease inhibitor cocktail (Roche). Protein extracts were sonicated and centrifuged for $12 \mathrm{~min}$ at $16,000 \mathrm{~g}$. The protein concentration of the cell lysates was determined using the micro-bicinchoninic acid assay, and $50 \mu \mathrm{g}$ were run on SDS-PAGE (10\% polyacrylamide gels) in denaturing conditions, and transferred onto PVDF membrane sheets (Bio-Rad, Hercules, CA). After unbound sites were blocked, blots were probed overnight with $5 \%$ fat milk in PBS, $0.1 \%$ tween 20, and either mouse monoclonal anti-STIM1 (GOK; 1:1000), rabbit polyclonal anti-Orai1 (1:1000; Sigma Aldrich), mouse monoclonal anti-TRPC1 (E6; 1:1000; Santa Cruz, Dallas, TX) or mouse monoclonal anti-GAPDH antibody (6C5; 1:10,000; Abcam, Cambridge, UK). Washed blots were incubated with Horseradish Peroxidase (HRP)-conjugated goat anti-mouse or rabbit IgG Ab (1:10,000; Abcam). Image acquisition was performed on a Chemi-Smart 5100 system (VilberLourmat) with the Chemi-Capt 5000 software and analysed on Image J. All results were normalized upon GAPDH quantification.

\section{Statistical analysis}

Continuous data are described as mean \pm standard error of the mean (SEM). Following normality and equality of variance tests, nominal values were compared to controls using the student's t test or alternatively by using a nonparametric test (Mann-Whitney rank sum test). Differences among groups were analyzed by one-way ANOVA in a non-parametric test and the Dunn's test was used for post-hoc comparisons. For categorical data the Fisher's exact test was used, and for correlation analysis the Pearson's coefficient $r$ was calculated. The profile likelihood method using a Cox regression model of PFS was used in univariate analysis to determine the optimal threshold and stratify patients into two groups as previously described [22]. PFS, TFS and LDT analyses were next performed using Kaplan-Meier curves and prognosis differences between groups were assessed with a log-rank test. Receiver operating curves (ROC) were generated to determine the area under the curve (AUC) and the optimal cut-off values were chosen by using the upper left corner value (100\% specificity). $P$ values under 0.05 were considered significant. Statistical analyses and the correlation matrix were performed using GraphPad Prism 7.0a (La Jolla, CA).

\section{Results}

Constitutive $\mathrm{Ca}^{2+}$ entry is higher in unstimulated $\mathrm{B}-\mathrm{CLL}$ cells from patients with progressive disease

As deregulation in $\mathrm{Ca}^{2+}$ signaling is an important hallmark of B-CLL cells, and suspected to vary during CLL disease progression [2], $\mathrm{Ca}^{2+}$ entry in the absence of BCR engagement, designated as $\mathrm{CE}$, was evaluated in resting B-CLL cells. To this end 30 untreated CLL patients were selected and, as reported in Fig. 1a, CE was significantly enhanced in a subset of B-CLL cells when compared to $\mathrm{B}$ cells from 8 healthy controls $\left(\Delta \mathrm{F} / \mathrm{F}_{0}\right.$ : $0.10 \pm 0.01$ in B-CLL cells versus $0.06 \pm 0.01$ in controls, $P=0.03)$. CLL patients were further dichotomized into $\mathrm{CE}+$ (high levels) versus CE- (normal/low levels) using the profile likelihood method in a Cox regression model of PFS for optimal cut-off identification (cut-off $=0.083$ ).

Next, and according to this dichotomy, the KaplanMeier log-rank analysis revealed, for those CE+ CLL patients $(n=16)$, a significant difference with regards to parameters associated with disease outcome such as PFS $(P=0.001$; Fig. $1 b)$, TFS $(P=0.003$; Fig. $1 c)$ and LDT $(P$ $=0.02$; Fig. $1 \mathrm{~d})$. In addition, the Binet status $(p=0.0002)$ and lymphocytosis $(P=0.003)$ were associated with an elevated $C E$, which was not the case for the cytogenetic risk status, $\operatorname{IgHV}$ mutational status, and CD38 positivity (Table 1, left part).

Constitutive $\mathrm{Ca}^{2+}$ entry is independent from proximal BCR signaling and BCR co-activators

One step further, to test BCR pathway dependence in $\mathrm{CE}+\mathrm{B}-\mathrm{CLL}$ cells, the BCR capacity to mobilize $\mathrm{Ca}^{2+}$ was tested within B-CLL cells from 16 CE+ CLL patients, 13 CE- CLL patients, and 13 healthy controls (Fig. 2a and Additional file 2: Figure S2). As previously described [2, 3 ], $\mathrm{Ca}^{2+}$ mobilization in response to $\mathrm{BCR}$ engagement was reduced in B-CLL cells when compared to controls ( $P=0.002$ for both CE subgroups), however no difference was observed when comparing the two CE subgroups within CLL patients. Interestingly, by conducting a bivariate analysis of PFS on both $\mathrm{CE}$ and $\operatorname{IgM~} \mathrm{Ca}^{2+}$ mobilization, we further observed that CLL patients with disease progression were restricted to $\mathrm{CE}+/ \operatorname{IgM}+(n=$ $11)$ and $C E+/ \operatorname{IgM}-(n=5) \mathrm{CLL}$ patients but not to $\mathrm{CE}$ $-/ \operatorname{IgM}+(n=4)$ and CE-/IgM- $(n=9)$ CLL patients $(P=$ 0.006, Fig. 2b). To dissect heterogeneity between the 4 subgroups of patients (Additional file 2: Table S1), we next examined whether these differences resulted from differential expression of the membrane surface (s) IgM, sIgD, and co-receptors (CD19, CD21, CD38, and CD5). No differences were observed between the 4 subgroups for these markers that participate or modulate the proximal BCR signaling. As well, no differences were reported when considering $\mathrm{CE}+$ and CE- CLL patients. 

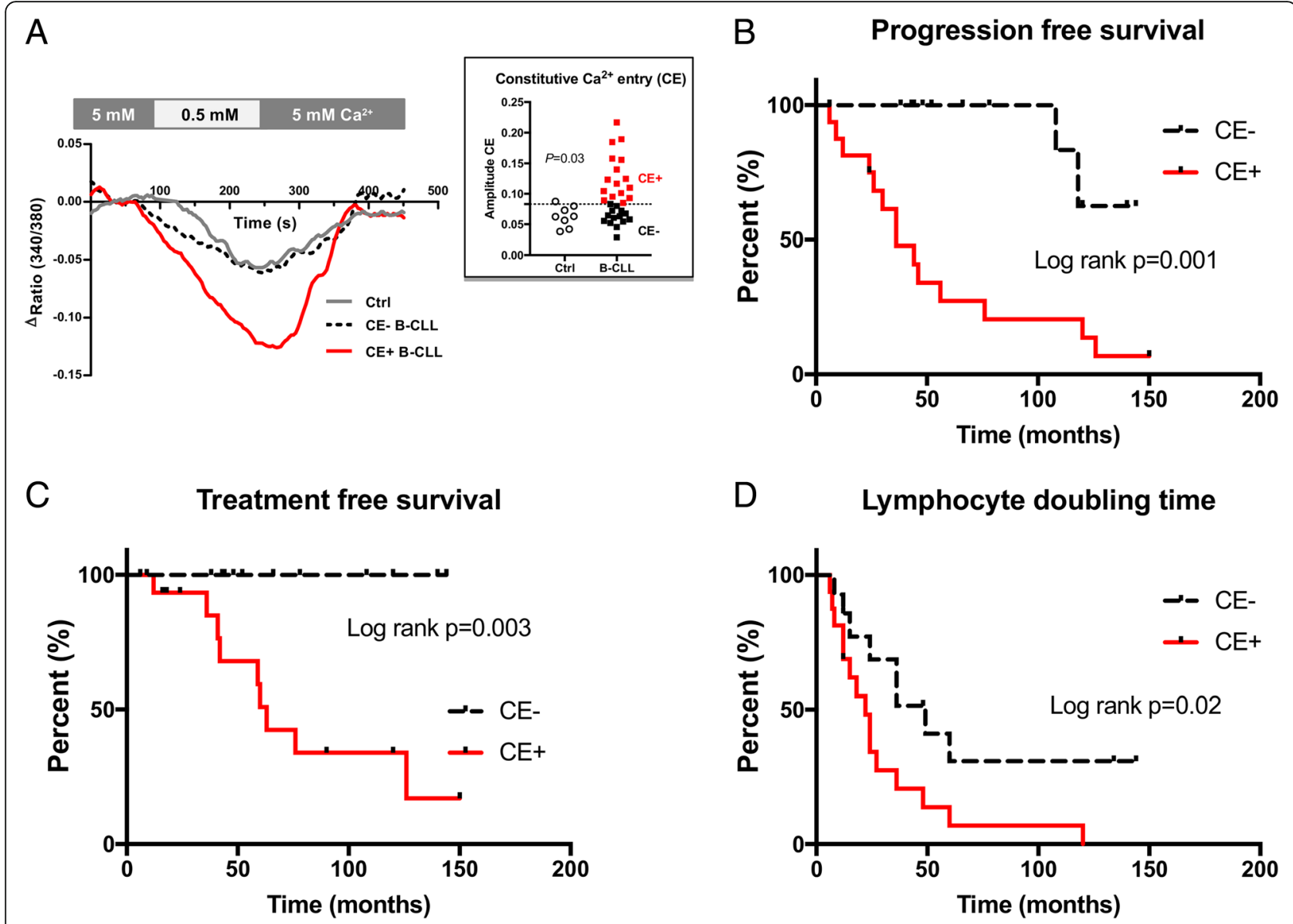

Fig. 1 An elevated level of constitutive calcium entry (CE) is relevant for chronic lymphocytic leukemia (CLL) clinical outcome. a- Representative kinetic plots of CE in representative healthy control B cells $(n=8, C$ trl), CE- B-CLL $(n=13)$ and CE+ B-CLL $(n=17)$ samples. A Cox regression model of progression free survival was used to dichotomize CLL patients in CE- and CE+ (dash line in the islet). Kaplan-Meier plots showing: b- time to progression free survival; c- time to treatment free survival; and $\mathbf{d}$ - lymphocyte doubling time between CE+ and CE- CLL groups. $P$ values are indicated when significant

Accordingly, we concluded that there is independence of CE from proximal BCR signaling and BCR co-activators.

\section{Constitutive $\mathrm{Ca}^{2+}$ entry is independent from an autonomous BCR pathway}

Since CE could be attributable to an antigen-independent autonomous BCR pathway [15], this $\mathrm{Ca}^{2+}$ entry was recorded in the presence of two BCR signalosome inhibitors Ibrutinib, a covalent inhibitor of BTK, and LY294002, a selective inhibitor of PI3K $\delta$. As shown in Fig. 2c/d, CE+ B-CLL cells from 3 patients were selected and CE was unaffected by the addition of the BCR signaling inhibitors. In parallel and as a positive control, the Ibrutinib and LY294002 capacity to inhibit $\mathrm{Ca}^{2+}$ response following BCR activation was demonstrated (Fig. 2e/f). Such a concept was further reinforced by the analysis of basal pPLC 2 , an indicator of BCR signalosome activation, in resting $\mathrm{B}-\mathrm{CLL}$ cells showing that $\mathrm{pPLC} 2$ levels were similar between the $\mathrm{CE}+$ and $\mathrm{CE}$ - CLL subgroups (Additional file 2: Table S1).

\section{Constitutive $\mathrm{Ca}^{2+}$ entry is correlated with basal $\mathrm{Ca}^{2+}$ levels} and independent from SOCE

Next, 29 B-CLL cells (10 CE-/IgM-, 4 CE+/IgM+, 4 CE +/IgM- and $11 \mathrm{CE}+/$ IgM+) were selected and a correlation matrix was performed for all in order to compare $\mathrm{CE}$ with (i) the basal intracellular $\mathrm{Ca}^{2+}$ level estimated by the initial $\mathrm{F} 340 / 380$ ratio, (ii) the anti-IgM Ca ${ }^{2+}$ response; (iii) the ER $\mathrm{Ca}^{2+}$ release by thapsigargin (TG), an inhibitor of the ER $\mathrm{Ca}^{2+}$ ATPase pumps, that artificially and maximally deplete $\mathrm{Ca}^{2+}$ stores in the absence of extracellular $\mathrm{Ca}^{2+}$; and (iv) the TG SOCE response observed after $\mathrm{Ca}^{2+}$ reffiling.

Results from the correlation matrix were effective to highlight two groups of $\mathrm{Ca}^{2+}$ responses in B-CLL cells (Additional file 2: Figure S3A/B). First an association based on the correlation observed between $\mathrm{CE}$ and the 
Table 1 Clinical data of the 30 untreated CLL patients tested for Ca2+ entry and dichotomized into CE+ (high constitutive $\mathrm{Ca}^{2+}$ entry [CE]) and CE- (low/normal CE levels) and of the whole CLL cohort $(n=74)$, dichotomized according to the level of STIM1 located in the plasma membrane (STIM1 $\left.1_{\mathrm{PM}}\right)$ in high and low

\begin{tabular}{|c|c|c|c|c|c|c|}
\hline & $\begin{array}{l}\text { CE- } \\
(n=14)\end{array}$ & $\begin{array}{l}\text { CE+ } \\
(n=16)\end{array}$ & Statistics & $\begin{array}{l}\text { High STIM1PM } \\
(n=28)\end{array}$ & $\begin{array}{l}\text { Low STIM1 } 1 \text { PM } \\
(n=44)\end{array}$ & Statistics \\
\hline Age diagnosis (years), mean \pm SEM & $63 \pm 3$ & $62 \pm 2$ & NS & $63 \pm 2$ & $64 \pm 2$ & NS \\
\hline Age analysis (years) & $69 \pm 4$ & $67 \pm 2$ & NS & $70 \pm 2$ & $70 \pm 2$ & NS \\
\hline Sex F:M & $4: 10$ & $8: 8$ & NS & $14: 14$ & $16: 32$ & NS \\
\hline Binet $A / B / C$ & $12 / 2 / 0$ & $2 / 12 / 2$ & 0.0002 & $13 / 10 / 5$ & $31 / 10 / 3$ & NS \\
\hline Cytogenetic risks, No (\%) & & & NS & & & NS \\
\hline Low (isolated d13q) & $6 / 12(50 \%)$ & $8 / 16(50 \%)$ & & $13 / 26(50 \%)$ & $21 / 37(56.8 \%)$ & \\
\hline Intermediate (tri12, normal karyotype) & $6 / 12(50 \%)$ & $5 / 16(31 \%)$ & & 9/26 (34.6\%) & 13/37 (35.1\%) & \\
\hline High (d11q, d17p, complex karyotype) & $\begin{array}{l}0 / 11 \\
(0 \%)\end{array}$ & $3 / 16(19 \%)$ & & $4 / 26(15.4 \%)$ & $3 / 37(8.1 \%)$ & \\
\hline IgHV UM:M & $0: 7$ & $0: 10$ & NS & $3: 14$ & $3: 21$ & NS \\
\hline CD38 (> 30\%) & $\begin{array}{l}1 / 12 \\
(8 \%)\end{array}$ & $4 / 15(27 \%)$ & NS & $7 / 28(25 \%)$ & 6/45 (13.3\%) & NS \\
\hline Lymphocytosis (Giga/L) & $30 \pm 4$ & $74 \pm 12$ & 0.003 & $57.2 \pm 9.2$ & $34.6 \pm 3.5$ & 0.05 \\
\hline PFS (median-months) ${ }^{a}$ & $>150$ & 44 & 0.001 & 46 & 120 & 0.0007 \\
\hline TFS (median-months) ${ }^{a}$ & $>150$ & 63 & 0.003 & 116 & $>120$ & 0.02 \\
\hline LDT (median months) ${ }^{a}$ & 49 & 22 & 0.02 & 24 & 36 & NS \\
\hline
\end{tabular}

Abbreviations: NS not significant, No number, SEM standard error of the mean, IGHV immunoglobulin heavy-chain variable region, UM unmutated IGHV, M mutated

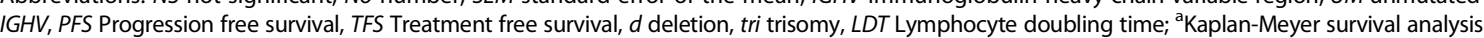

basal $\mathrm{Ca}^{2+}$ level $(\mathrm{r}=0.591 ; P=0.001)$, but not $\mathrm{CE}$ with anti-IgM and Tg SOCE response (data not shown). Second, a proximal BCR-InsP3R signaling pathway as the anti-IgM $\mathrm{Ca}^{2+}$ response was correlated with both TG ER $\mathrm{Ca}^{2+}$ release and TG SOCE $\left(P=3 \times 10^{-4}\right.$ and $1 \times 10^{-7}$, respectively) but not with basal $\mathrm{Ca}^{2+}$ levels and $\mathrm{CE}$.

\section{Constitutive $\mathrm{Ca}^{2+}$ entry is regulated by STIM1and supported by Orai1 and TRPC1 channels}

Based on our previous work showing a role for Orail, TRPC1 channels and STIM1 $[17,23]$ in CE, and to better characterize the autonomous $\mathrm{Ca}^{2+}$ channel influx in $\mathrm{CE}+\mathrm{B}-\mathrm{CLL}$ cells, three strategies were developed using (1) the Orail channel blocker, Synta66 (S66); (2) specific siRNA for Orai1, TRPC1 and STIM1 to modulate CE amplitude; and (3) a quantitative analysis of Orai1, TRPC1 and STIM1 expression by Western-blot.

First, specific blockade of Orail channels with S66 at $2.5 \mu \mathrm{M}$ significantly reduced $\mathrm{CE}(P=0.03)$, the anti-IgM $\mathrm{Ca}^{2+}$ response $(P=0.01)$, and TG SOCE $(P=0.05)$ but not TG ER $\mathrm{Ca}^{2+}$ release in CE+/IgM+ B-CLL cells compared to control conditions (Fig. 3a/b and data not shown). Second, and another way in which to further test our hypothesis, was to reduce the expression of Orai1, TRPC1 and/or STIM1 by transfecting specific siRNA into B-CLL cells ( $1 \mathrm{CE}+/ \mathrm{IgM}-$ and $2 \mathrm{CE}+/ \mathrm{IgM}+)$. In contrast to the negative siRNA control, a reduction was seen at the protein level when using specific siRNAs for STIM1, Orail, and TRPC1 (FACS representations are depicted Fig. 3c). As a result, $\mathrm{CE}$ was reduced in the presence of siRNA to Orail, TRPC1 and STIM1 $(P<$ 0.05 for all) (Fig. 3d). These results suggest that Orai1 together with TRPC1 both contribute to CE regulated by STIM1.

Third, Western blot (WB) was used to analyze the expression of Orai1, STIM1 and TRPC1 isoforms in B-CLL cells from 19 patients (11 CE+ and $8 \mathrm{CE}-)$. When comparing $\mathrm{CE}+$ and $\mathrm{CE}$ - patients (Fig. 4), the two different isoforms of Orail were increased $(P=0.04)$, and, although not significant, there is a trend for higher TRPC1 expression in CE+ B-CLL cells compared to CEB-CLL cells. STIM1 analysis by WB reveals higher expression of both the $75 \mathrm{kDa}$ non-glycosylated isoform and the $85 \mathrm{kDa}$ glycosylated isoform that were overexpressed in CE+ B-CLL cells $(P=0.03)$.

\section{The pool of STIM1 located in the plasma membrane (STIM1 $1_{\mathrm{PM}}$ ) controls CE}

Since glycosylation is required for STIM1 localization at the plasma membrane $[24,25]$, and given that the pool of STIM1 located in the plasma membrane (STIM1 $1_{\mathrm{PM}}$ ) regulates store-independent $\mathrm{Ca}^{2+}$ influx [26], this raises the possibility that STIM1 $1_{\mathrm{PM}}$ controls $\mathrm{CE}$ and contributes to its enhancement in CE+ B-CLL cells. To address this issue (Fig. 5a), B-CLL cells from 28 patients (11 CE+ and 17 CE-) were tested by FACS for STIM1 expression using STIM1 mAb following permeabilization of the cells (total-STIM1 expression determination) or not 


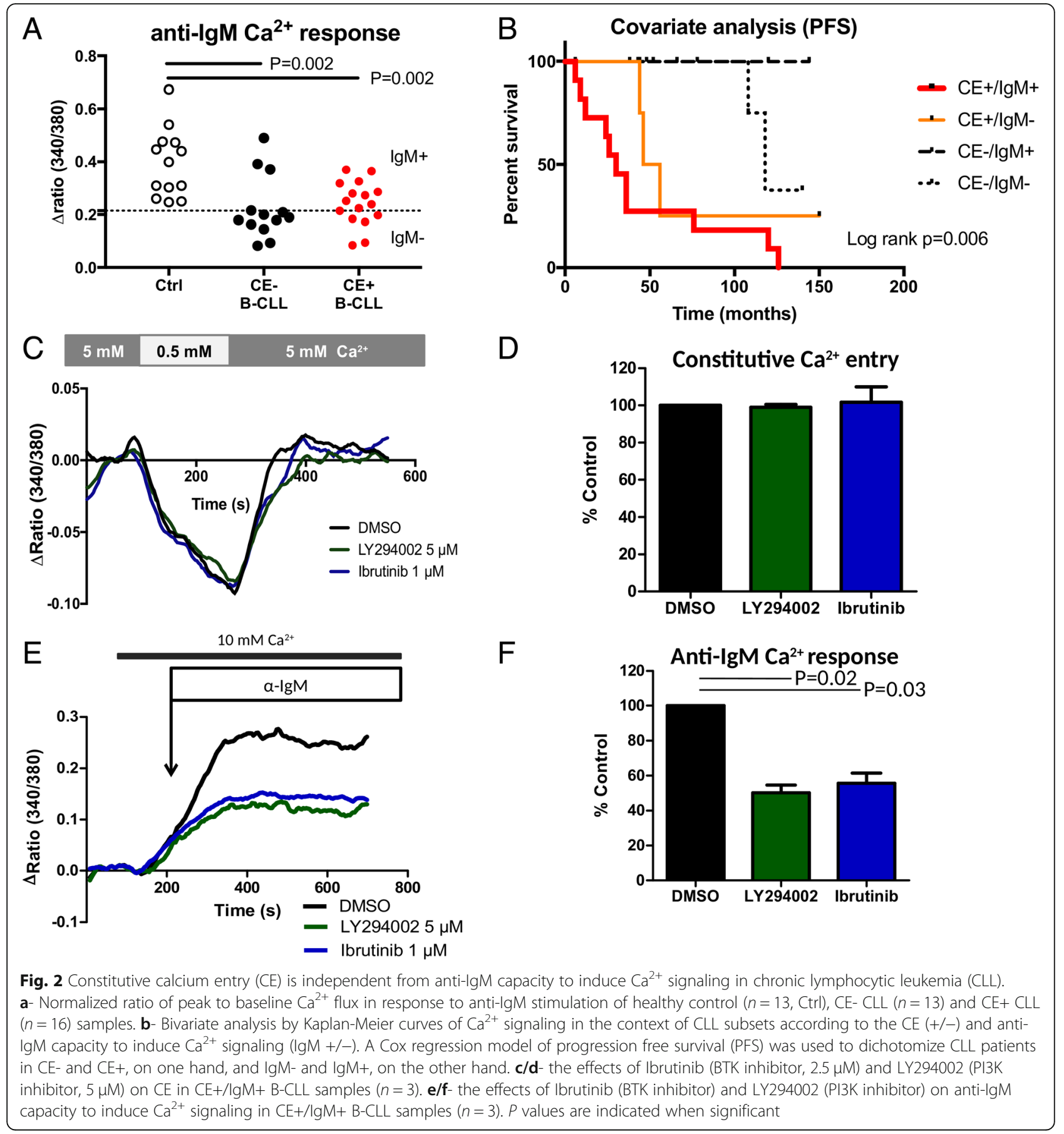

(STIM1 $_{\mathrm{PM}}$ quantification). In agreement with WB results, FACS analysis revealed that both total-STIM1 and STIM1 $_{\mathrm{PM}}$ were increased in CE+ B-CLL cells $(P=0.01$ and $<10^{-4}$, respectively), and their levels correlated with CE amplitude ( $P=0.01$ both, Fig. 5 b). A ROC analysis was performed in order to establish the cut-off for positivity (Fig. 5b left). We next sought to determine STIM1 $1_{\mathrm{PM}}$ involvement in CE regulation, and this was tested by exploring the capacity of the anti-STIM1 mAb
(GOK, $10 \mu \mathrm{g} / \mathrm{mL}$ ) to inhibit CE. In contrast to the IgG2a isotype control $\mathrm{mAb}$ that had no effect on $\mathrm{CE}$ (Fig. 5c), the anti-STIM1 $1 \mathrm{mAb}$ inhibits $\mathrm{CE}(P=0.03)$, while no effects were reported on the anti-IgM $\mathrm{Ca}^{2+}$ response, TG ER $\mathrm{Ca}^{2+}$ release and TG SOCE responses (Fig. 5d and Additional file 2: Figure S4B). This is in agreement with the observed correlation between STIM1 $1_{\mathrm{PM}}$ levels and basal $\mathrm{Ca}^{2+}$ but not with TG ER $\mathrm{Ca}^{2+}$ release and IgM/ TG SOCE results (Additional file 2: Figure S4A). 


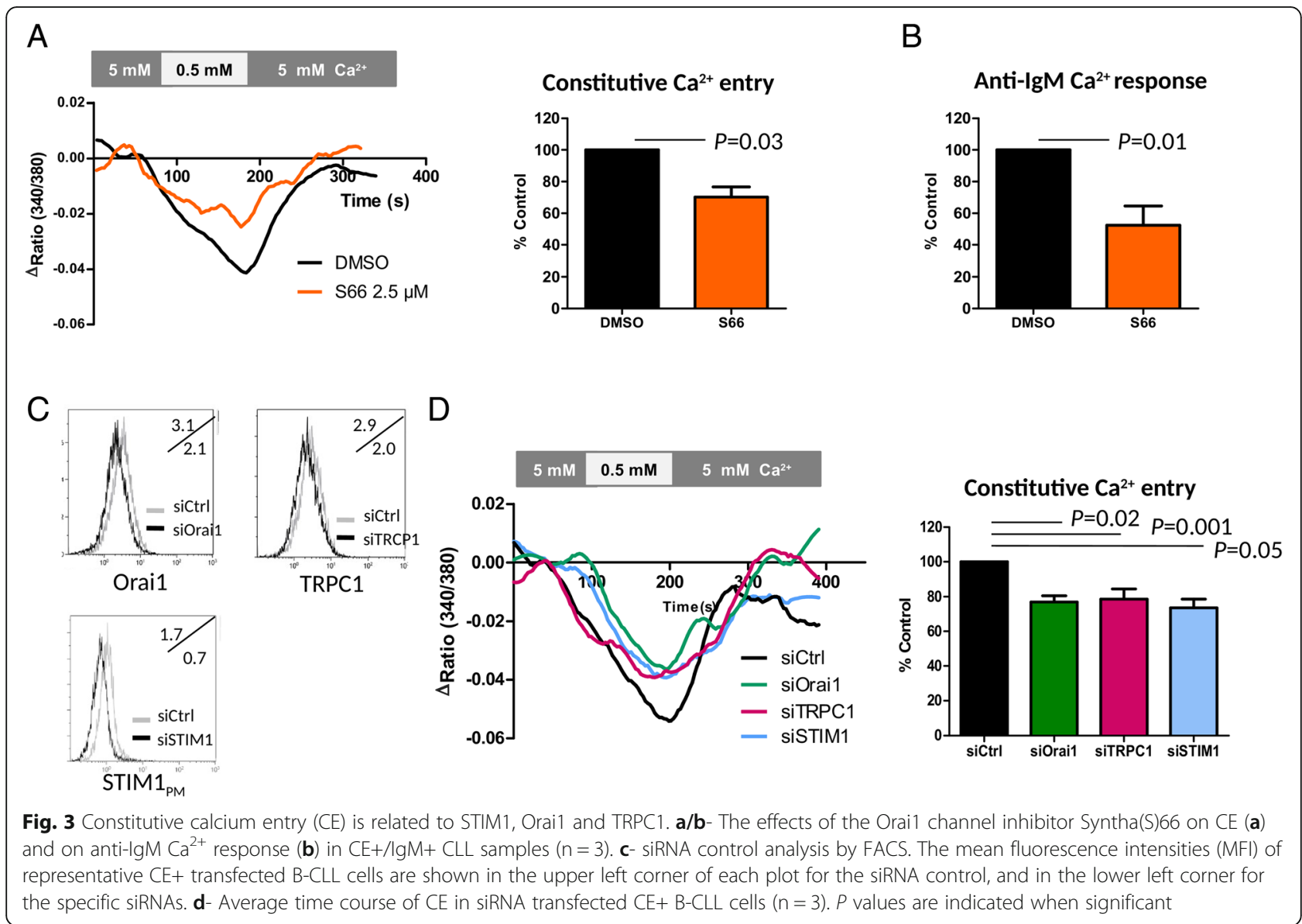

Altogether this reinforces our hypothesis that $\mathrm{CE}$ and basal $\mathrm{Ca}^{2+}$ are regulated by STIM1 $1_{\mathrm{PM}}$ and supported by Orai1 and TRPC1 channels in a unique and alternative influx pathway distinct from SOCE and downstream the BCR-InsP3R pathway.

\section{STIM1 $1_{\mathrm{PM}}$ as a valuable therapeutic target}

As $\mathrm{CE}$ determination is difficult to manage in routine practice, we further compared the patient's characteristics according to their plasma membrane STIM1 status in 74 untreated CLL that included those tested for $\mathrm{Ca}^{2+}$ signaling. As depicted in the Kaplan-Meyer curves (Fig. 6a), the CLL STIM1 $1_{\mathrm{PM}}$ high subgroup had shorter PFS and TFS $(P=0.0007$ and $P=0.02$, respectively). Characteristics of STIM1 $1_{\mathrm{PM}}$ high and low patients are presented in Table 1 (right part) showing that lymphocytosis $(p=0.05)$, but not the other parameters tested, was increased in the CLL STIM1 $1_{\mathrm{PM}}$ high subgroup.

Finally and as the initial descriptions of STIM1 $1_{\mathrm{PM}}$ were related to the control of cell survival [27, 28], we next decided to test the neutralizing capacity of the anti-STIM1 mAb clone GOK to control B-CLL cell survival $\left(\mathrm{STIM}_{\mathrm{PM}}\right.$ high $n=9$; and STIM1 $1_{\mathrm{PM}}$ low $n=8$ ) when used alone or in combination with RTX, an
anti-CD20 mAb (Fig. 6b). Used alone GOK and RTX did not reduce in vitro B-CLL cell survival as compared to the controls, but in contrast the RTX + GOK combination significantly reduced cell viability in the STIM1 $1_{\mathrm{PM}}$ high subgroup $(50.4 \pm 6.4 \%$ with $\operatorname{IgG2a}$ versus $23.0 \pm$ $4.7 \%$ with RTX $+\mathrm{GOK}, P=0.03)$, an effect which was not significant in the STIM1 $1_{\mathrm{PM}}$ low subgroup $(33.5 \pm$ $6.5 \%$ with IgG2 versus $20.3 \pm 4.7 \%$ with $\mathrm{RTX}+\mathrm{GOK})$.

\section{Discussion}

The overall data add new support to the critical role played by the $\mathrm{Ca}^{2+}$ signaling in CLL outcome, and describe for the first time a novel STIM1 $1_{\mathrm{PM}^{-}}$-dependant and constitutively active $\mathrm{Ca}^{2+}$ entry, independent from $\mathrm{BCR}$ signaling, and that constitutively active CE can be modulated and targeted by an anti-STIM1 mAb. We found that both $\mathrm{CE}$ and $\mathrm{STIM} 1_{\mathrm{PM}}$ are clinically relevant in CLL and their determinations present important prognostic value.

Several reports have demonstrated altered $\mathrm{Ca}^{2+}$ signaling in CLL $\mathrm{B}$ cells and with the paradox that $\mathrm{Ca}^{2+}$ mobilization is altered in "anergic" CLL B cells from non-progressive patients, while a response is reported in CLL B cells from patients with disease progression as 

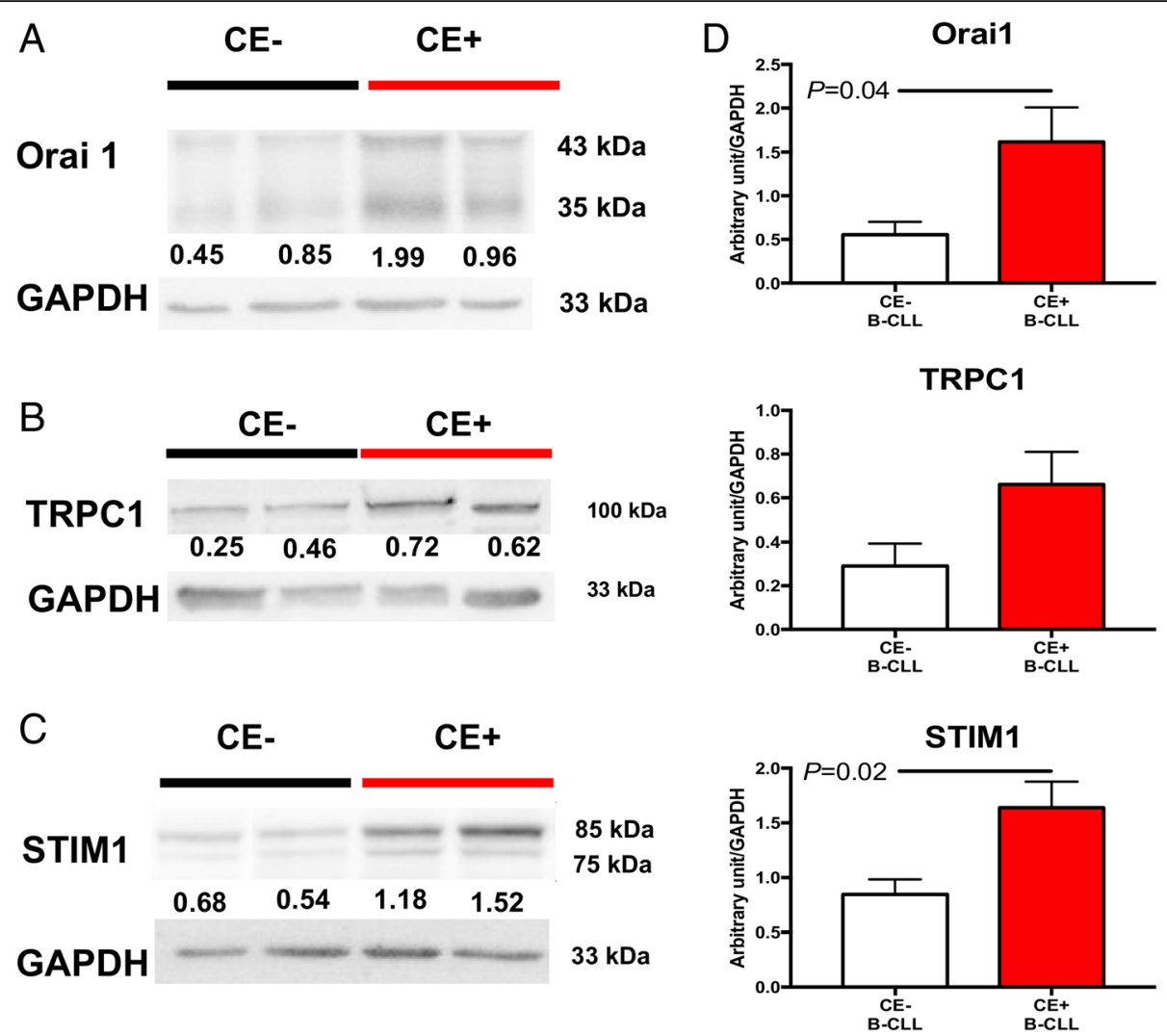

Fig. 4 B-CLL cells from CE+ CLL patients $(n=11)$ display increased Orai1 and STIM1 protein levels compared with those from CE- CLL patients $(n=8)$. Left panels, representative Western blot images for Orai1(a), TRPC1 (b), and STIM1 (c). Quantification after normalization to GAPDH protein expression is depicted (d). $P$ values are indicated when significant

observed in our study $[2,3]$. Moreover and based on the strong correlation observed between $\mathrm{CE}$ and basal cytosolic $\mathrm{Ca}^{2+}$ concentrations in this study, we were able to extend the observation performed by Muggen and colleagues who have described elevated basal $\mathrm{Ca}^{2+}$ concentrations in B-CLL cells in contrast to normal B cells [14]. Our study also supports that $C E$ and the elevated level of basal $\mathrm{Ca}^{2+}$ reported in B-CLL cells are, in fact, independent from the BCR-PLC $\gamma 2-\mathrm{InsP}_{3} \mathrm{R}$ pathway and are instead related to an enhanced $\mathrm{CE}$ and are independent from store depletion. In contrast, Duhren-Von Minden and colleagues have associated the elevated basal $\mathrm{Ca}^{2+}$ signaling downstream Syk phosphorylation in CLL $B$ cells to an antigen-independent recognition of the BCR framework domains (FR2 or FR3), or alternatively through an occupation of the BCR with repetitive motifs [15]. Importantly, blocking the BCR pathway with the BTK inhibitor ibrutinib or with the PI3K inhibitor LY294002 did not alter CE or the basal $\mathrm{Ca}^{2+}$ level (data not shown) which is in agreement with Muggen report who failed to associate the basal $\mathrm{Ca}^{2+}$ level in CLL B cells with the FR2/3 amino-acid sequence. Based on the report of Le Roy and colleagues who detected pSyk at a basal level in IgM+ responder patients, it could be proposed that blocking pSYK controls both $\mathrm{CE}$ and the IgM response in $\mathrm{CE}+/ \mathrm{IgM}+$ responder patients, an hypothesis that needs to be tested as well as the capacity of Syk to phosphorylate STIM1 [2, 3].

STIM1 was initially identified as a plasma membrane protein [25], and more recently STIM1 $1_{\mathrm{PM}}$ was associated with the regulation of a store independent $\mathrm{Ca}^{2+}$ entry pathway activated by arachidonic acid [26] and to SOCE in platelets [29]. Similarly and although STIM1 is predominantly located in the ER in normal B cells, we found that CE+ B-CLL cells express a substantial amount of STIM1 $1_{\mathrm{PM}}$ and Orai1 as well as an enhanced expression of TRPC1. This is important because STIM1 $_{\mathrm{PM}}$ can interact with Orai1 or TRPC1, two $\mathrm{Ca}^{2+}$ channels activated in CE+ B-CLL cells as demonstrated by using specific siRNAs and in agreement with the Chen KT et al. report [30]. STIM1 deregulation in B-CLL cells needs further exploration as it may be related to defective transcriptional control by DNA methylation and/or microRNAs [31,32], and/or is related to post-translational modifications such as glycosylation and/or phosphorylation known to affect STIM1 localization and properties [24, 33], as these processes are altered during CLL evolution [34]. 


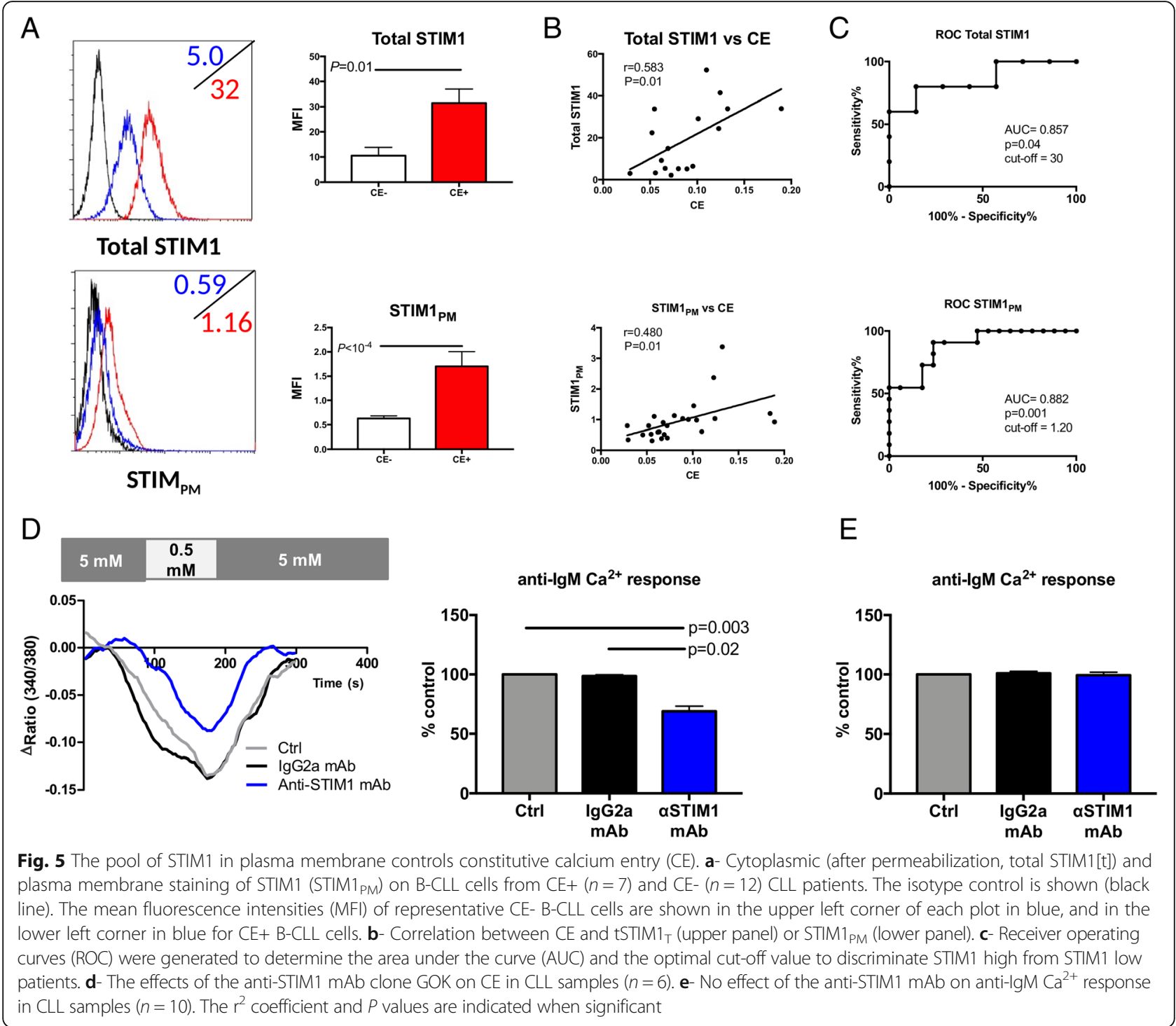

The clinical success of RTX in monotherapy is limited in CLL and, in order to improve its efficacy, RTX is associated with chemotherapy (RFC) or with BCR inhibitors (Ibrutinib, Idelalisib, venetoclax), however relapses and side-effects remain important suggesting a need to develop new therapeutical options and in particular to combine RTX with new drugs targeting a non BCR survival pathway $[35,36]$. Consistent with the notion that $\mathrm{CE}$ is important for disease outcome and STIM1 $1_{\mathrm{PM}}$ for CE, we demonstrated that pre-incubating cells with antibodies targeting STIM1 $1_{\mathrm{PM}}$ reverses B-CLL cell capacity for CE and in turn impairs cell survival when associated with RTX. Therefore, we propose to use anti-STIM1 $\mathrm{mAb}$ targeting $\mathrm{STIM} 1_{\mathrm{PM}}$ and $\mathrm{CE}$ as a new innovative therapeutic option for CLL. An additive/synergic effect of RTX or BCR inhibitors with CE inhibitors, such as anti-STIM1 $\mathrm{mAb}$, should be addressed in future studies.

Relevant limitations of our study include the following: (i) a small sample size used to analyze $\mathrm{Ca}^{2+}$ entry in CLL B cells; (ii) the use of samples from a cross-sectional and monocentric center; and (iii) a bias due to the selection of untreated patients. However and to reduce these limitations, a large panel of approaches (e.g. $\mathrm{Ca}^{2+}$ signaling, siRNAs, specific inhibitors, FACS, WB) has been used in order to demonstrate that STIM1 and in particular STIM1 $1_{\mathrm{PM}}$ controls CE in CLL B cells from patients with progressive disease. The selection of untreated patients for this study represents also an advantage as drug exposure may affect the analysis of $\mathrm{Ca}^{2+}$ entry, as observed in vitro with ibrutinib. Future studies are however mandatory in order to study whether variations 


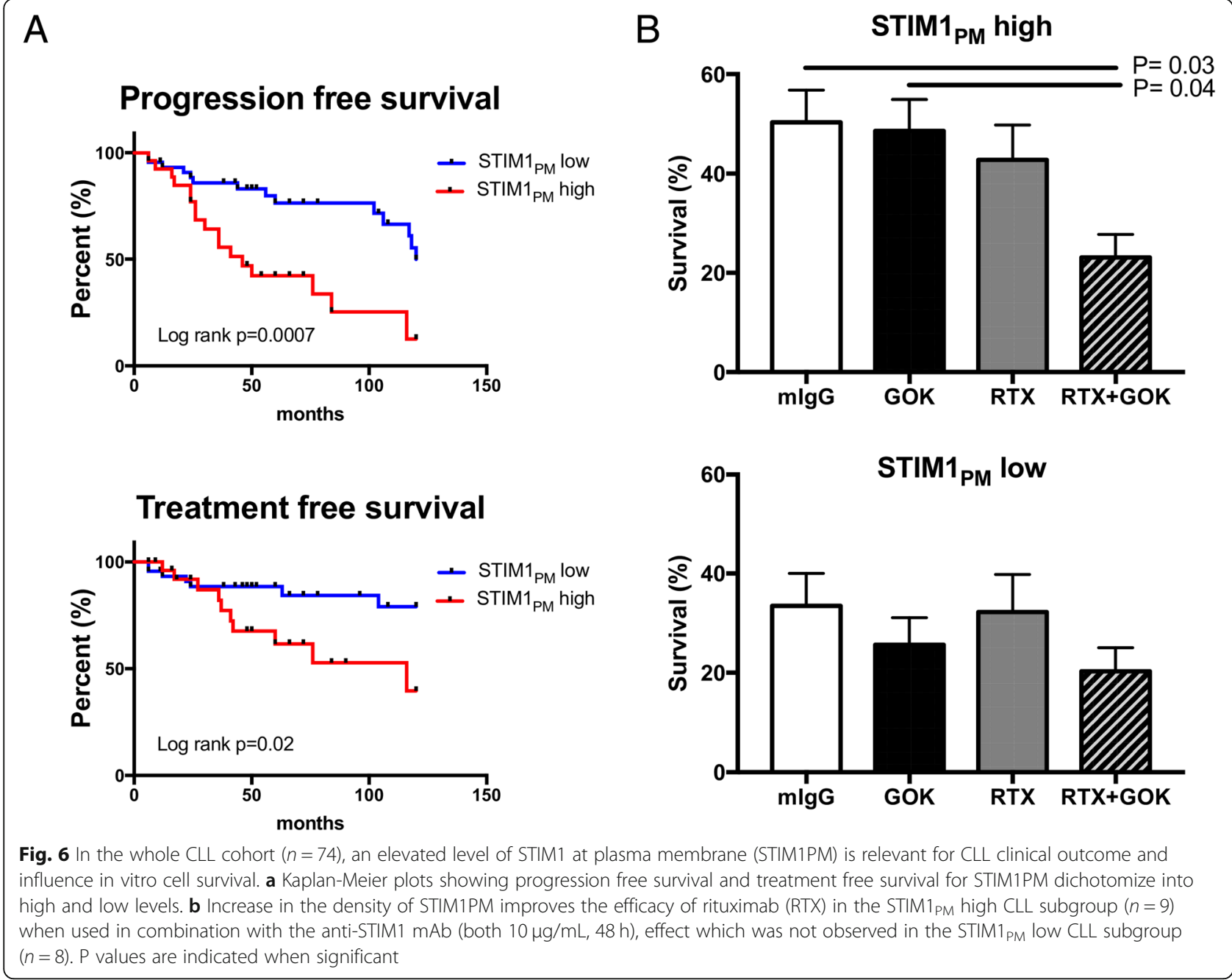

in $\mathrm{Ca}^{2+}$ entry and $\mathrm{Ca}^{2+}$ actor variations vary following treatment introduction and in those patients who relapse.

\section{Conclusion}

In CLL the involvement of $\mathrm{Ca}^{2+}$ signaling deregulation in cancer cell progression is well established, but the identification of mechanisms controlling $\mathrm{Ca}^{2+}$ entry are poorly understood. In the present work, an extensive analysis of the $\mathrm{Ca}^{2+}$ entry in CLL cells was performed, revealing, in patients with progressive disease, the implication of a constitutive and BCR-independent $\mathrm{Ca}^{2+}$ entry pathway. Next, it was further observed that a pool of STIM1 present in the plasma membrane characterizes tumor progression and controls constitutive $\mathrm{Ca}^{2+}$ entry. Finally, the capacity of an anti-STIM1 mAb to block constitutive $\mathrm{Ca}^{2+}$ entry and to reduce in vitro CLL cell viability, when associated with Rituximab, was reported within the high STIM1 $1_{\mathrm{PM}}$ CLL subgroup. This supports the idea that targeting STIM1 $1_{\mathrm{PM}}$ and therefore constitutive
$\mathrm{Ca}^{2+}$ entry represents a new 1 st in class therapeutic pathway in leukemia treatment. The potential use of $\mathrm{mAb}$ targeting STIM1 $1_{\mathrm{PM}}$ in cancer therapy that can be used alone or in synergy with existing drugs needs to be further evaluated.

\section{Additional files}

Additional file 1: Figure S1. Two pathways control $\mathrm{Ca}^{2+}$ signaling in B cells from patients with chronic lymphocytic leukemia. In the BCR-induced store operated $\mathrm{Ca}^{2+}$ entry pathway, B cell receptor (BCR) interaction with the antigen results in the formation of the signalosome consisting of an active complex composed of the tyrosine kinases Lyn and Syk, B-cell linker protein (BLNK), Bruton-tyrosine-kinase (BTK), phospholipase C gamma 2 (PLCY2), and phosphatidylinositol-4,5-bisphosphate 3-kinase $\delta$ (PI3K $\delta$ ) that phosphorylates CD19. Signalosome activation cleaves the membrane phospholipid phosphatidyl inositol 4.5-biphosphate (InsP2) into diacylglycerol (DAG) and inositol 1,4,5-triphosphate (InsP3), which subsequently, through binding to the endoplasmic reticulum (ER) IP3 receptor (InsP $\left.\mathrm{R}_{3} \mathrm{R}\right)$, mobilizes initially $\mathrm{Ca}^{2+}$ from stores and secondarily extracellular $\mathrm{Ca}^{2+}$ through the interaction between the multimerized reticular stromal interaction molecule 1 $\left(\mathrm{STIM} 1_{\mathrm{ER}}\right)$ and the plasma-membrane Orai1 channel. In the constitutive $\mathrm{Ca}^{2+}$ 
pathway, $\mathrm{Ca}^{2+}$ entry is triggered by STIM1 located at the plasma-membrane (STIM1PM). (PPTX $90 \mathrm{~kb}$ )

Additional file 2 Table S1. B cell receptors (BCR) and co-receptors analysis in B-CLL cells $(n=30)$ according to the capacity of the cells to possess an elevated constitutive $\mathrm{Ca} 2+$ entry $(\mathrm{CE}+)$ and their capacity to mobilize $\mathrm{Ca} 2+$ in response to $\mathrm{BCR}$ engagement (lgM+). The phosphorylated phospholipase C $Y 2$ (pPLCY2), an immediate downstream BCR effector, was added to the list. Figure S2. Representative kinetic plots of anti-lgM $\mathrm{Ca}^{2+}$ response (A), and thapsigargin (TG) $\mathrm{Ca}^{2+}$ response (B) in representative healthy donor (HD) control B cells $(n=8)$, CE- B-CLL $(n=13)$ and CE+ B-CLL $(n=16)$ samples. Cox regression model of progression free survival (PFS) was used to dichotomize CLL patients in $\lg \mathrm{M}$ - and $\lg \mathrm{M}+$ (dash line). From the $\mathrm{TG} \mathrm{Ca}^{2+}$ response analysis, the basal $\mathrm{Ca}^{2+}$ level was evaluated before normalization (1), the TG capacity to release $\mathrm{Ca}^{2+}$ from the endoplasmic reticulum (ER), and the TG capacity to release SOCE following extracellular medium supplementation with $1.8 \mathrm{mM} \mathrm{Ca}^{2+}$. $P$ values are indicated when significant. Figure S3. Basal calcium (Ca2+) entry is related to constitutive calcium entry (CE) but not to store operated Ca2+ entry (SOCE), while the anti-lgM Ca2+ response correlated to thapsigargin (TG) capacity to induce endoplasmic reticulum (ER) Ca2+ release and SOCE. Figure S4. The pool of STIM1 in plasma membrane (STIM1 $1_{\mathrm{PM}}$ ) is correlated with basal $\mathrm{Ca}^{2+}$ levels but independent from anti-lgM Ca ${ }^{2+}$ response and thapsigargin (TG) capacity to release $\mathrm{Ca}^{2+}$ from the endoplasmic reticulum (ER) and to induce SOCE. Correlations between STIM1 $1_{\text {PM }}$ levels with basal $\mathrm{Ca}^{2+}(\mathrm{A})$, anti-IgM Ca ${ }^{+}$response (B), TG capacity to induce ER $\mathrm{Ca}^{2+}$ release (C), and TG SOCE (D). Values were obtained from $18 \mathrm{CLL}$, see material and methods for details. $P$ and $r^{2}$ values are indicated when significant. (DOCX $531 \mathrm{~kb}$ )

\section{Abbreviations}

BCR: B cell receptor; $\mathrm{Ca}^{2+}$ : Calcium; CE: Constitutive $\mathrm{Ca}^{2+}$ entry; CLL: Chronic lymphocytic leukemia; ER: Endoplasmic reticulum; FACS: Fluorescenceactivated cell sorting; InsP3: Inositol 1,4,5-triphosphate; InsP ${ }_{3} R$ : Inositol 1,4,5triphosphate receptor; LDT: Lymphocyte doubling time; mAb: Monoclonal antibody; mAb: Monoclonal antibody; PFS: Progression free survival; PLCY2: Phospholipase C gamma 2; RTX: Rituximab; siRNA: Small interfering RNA; SOCE: Store operated $\mathrm{Ca}^{2+}$ entry; STIM1: Stromal interaction molecule 1; STIM1 PM: Plasma-membrane STIM1; TFS: Treatment free survival; TG: Thapsigargin; WB: Western blot

\section{Acknowledgements}

We are thankful to Dr. Christelle Le Dantec and Dr. Pierre Pochard for technical assistance, to Dr. Wesley H. Brooks (University of South Florida, USA) for editorial assistance, and to Simone Forest and Genevieve Michel for secretarial help.

\section{Funding}

This study was supported by the "Lique against the cancer", section 29, the Brittany region, the Brest University Hospital INNOVEO donation fund, and SATT-Ouest valorization (Patents EP2982982 and EP3062105).

\section{Availability of data and materials}

The datasets used and/or analysed during the current study are available from the corresponding author on reasonable request.

\section{Authors' contributions}

YR, OM, CV and MPC designed the study. MD, MB, PH, PB, TF, SM, and NLG performed the research. CBa performed the clinical data gathering. AT and CBe took care of the patients and validated clinical data accuracy. MD, OM, JOP and YR analyzed the data. YR, OM and MD prepared the initial draft. The final manuscript was read and approved by all authors.

\section{Ethics approval and consent to participate}

This study was approved by the Ethical Board at the Brest University Hospital (OFICE, November 26th, 2015; clinicaltrials: NCT03294980) in accordance with the declaration of Helsinki.

\section{Consent for publication}

Written informed consent was obtained from all of the patients.

\section{Competing interests}

The authors declare that they have no competing interests.

\section{Publisher's Note}

Springer Nature remains neutral with regard to jurisdictional claims in published maps and institutional affiliations.

\section{Author details}

'INSERM U1227 B lymphocytes and autoimmunity, University of Brest, Brest, France. ${ }^{2}$ INSERM U1069, N2C, 37032, University of Tours, Tours, France. ${ }^{3}$ IC-CGO network from "Canceropole Grand Ouest", Brest, France. "Laboratory of Immunology and Immunotherapy, CHRU Brest Morvan, Brest, France. ${ }^{5}$ Department of Haematology, CHRU Brest Morvan, Brest, France.

Received: 30 January 2019 Accepted: 2 April 2019

Published online: 23 April 2019

\section{References}

1. Kipps TJ, Stevenson FK, Wu CJ, Croce CM, Packham G, Wierda WG, et al. Chronic lymphocytic leukaemia. Nat Rev Dis Primers. 2017;3:16096.

2. Le Roy C, Deglesne PA, Chevallier N, Beitar T, Eclache V, Quettier M, et al. The degree of BCR and NFAT activation predicts clinical outcomes in chronic lymphocytic leukemia. Blood. 2012;120(2):356-65

3. Nedellec S, Renaudineau Y, Bordron A, Berthou C, Porakishvili N, Lydyard PM, et al. B cell response to surface lgM cross-linking identifies different prognostic groups of B-chronic lymphocytic leukemia patients. J Immunol. 2005;174(6):3749-56

4. Baba Y, Kurosaki T. Physiological function and molecular basis of STIM1mediated calcium entry in immune cells. Immunol Rev. 2009;231(1):174-88.

5. Feske S. Calcium signalling in lymphocyte activation and disease. Nat Rev Immunol. 2007:7(9):690-702.

6. Mukherjee S, Karolak A, Debant M, Buscaglia P, Renaudineau Y, Mignen O, et al. Molecular dynamics simulations of membrane-bound STIM1 to investigate conformational changes during STIM1 activation upon calcium release. J Chem Inf Model. 2017:57(2):335-44.

7. Vaeth M, Maus M, Klein-Hessling S, Freinkman E, Yang J, Eckstein M, et al. Store-operated $\mathrm{Ca} 2+$ entry controls clonal expansion of T cells through metabolic reprogramming. Immunity. 2017;47(4):664-79 e6.

8. Vaeth M, Eckstein M, Shaw PJ, Kozhaya L, Yang J, Berberich-Siebelt F, et al. Store-operated $\mathrm{ca}(2+)$ entry in follicular T cells controls humoral immune responses and autoimmunity. Immunity. 2016;44(6):1350-64.

9. Debant M, Hemon P, Brigaudeau C, Renaudineau Y, Mignen O. Calcium signaling and cell fate: how can $\mathrm{Ca} 2+$ signals contribute to wrong decisions for chronic lymphocytic leukemic B lymphocyte outcome? Int J Dev Biol. 2015;59(7-9):379-89.

10. Hemon P, Renaudineau Y, Debant M, Le Goux N, Mukherjee S, Brooks W, et al. Calcium Signaling: From Normal B Cell Development to Tolerance Breakdown and Autoimmunity. Clin Rev Allergy Immunol. 2017;53(2):141-65. https://doi.org/10.1007/s12016-017-8607-6. Review. PubMed PMID: 28500564

11. Baba $Y$, Kurosaki T. Role of calcium signaling in B cell activation and biology Curr Top Microbiol Immunol. 2016:393:143-74.

12. Yarkoni $Y$, Cambier JC. Differential STIM1 expression in T and B cell subsets suggests a role in determining antigen receptor signal amplitude. Mol Immunol. 2011:48(15-16):1851-8.

13. D'Avola A, Drennan S, Tracy I, Henderson I, Chiecchio L, Larrayoz M, et al. Surface lgM expression and function are associated with clinical behavior, genetic abnormalities, and DNA methylation in CLL. Blood. 2016;128(6):816-26.

14. Muggen AF, Pillai SY, Kil LP, van Zelm MC, van Dongen J, Hendriks RW, et al. Basal $\mathrm{Ca}(2+)$ signaling is particularly increased in mutated chronic lymphocytic leukemia. Leukemia. 2015;29(2):321-8.

15. Duhren-von Minden M, Ubelhart R, Schneider D, Wossning T, Bach MP, Buchner $\mathrm{M}$, et al. Chronic lymphocytic leukaemia is driven by antigenindependent cell-autonomous signalling. Nature. 2012;489(7415):309-12

16. Zhong F, Harr MW, Bultynck G, Monaco G, Parys JB, De Smedt H, et al. Induction of ca(2)+-driven apoptosis in chronic lymphocytic leukemia cells by peptide-mediated disruption of Bcl-2-IP3 receptor interaction. Blood. 2011:117(10):2924-34

17. Garaud S, Taher TE, Debant M, Burgos M, Melayah S, Berthou C, et al. CD5 expression promotes IL-10 production through activation of the MAPK/Erk pathway and upregulation of TRPC1 channels in B lymphocytes. Cell Mol 
Immunol. 2018;15(2):158-170. https://doi.org/10.1038/cmi.2016.42. Epub 2016 Aug 8. PubMed PMID: 27499044; PubMed Central PMCID:PMC5811677.

18. Vaisitti T, Audrito V, Serra S, Buonincontri R, Sociali G, Mannino E, et al. The enzymatic activities of CD38 enhance CLL growth and trafficking: implications for therapeutic targeting. Leukemia. 2015;29(2):356-68.

19. Swerdlow SH, Campo E, Harris NL, Jaffe ES, Pileri SA, Stein H, et al. WHO Classification of Tumours of Haematopoietic and Lymphoid Tissues. OMS ed. Tumours WCo, editor 2008:

20. Bagacean C, Tempescul A, Patiu M, Fetica B, Bumbea H, Zdrenghea M. Atypical aleukemic presentation of large granular lymphocytic leukemia: a case report. Onco Targets Ther. 2017;10:31-4.

21. Garaud S, Morva A, Lemoine S, Hillion S, Bordron A, Pers JO, et al. CD5 promotes IL-10 production in chronic lymphocytic leukemia B cells through STAT3 and NFAT2 activation. J Immunol. 2011;186(8):4835-44.

22. Bagacean C, Le Dantec C, Berthou C, Tempescul A, Saad H, Bordron A, et al. Combining cytogenetic and epigenetic approaches in chronic lymphocytic leukemia improves prognosis prediction for patients with isolated 13q deletion. Clin Epigenetics. 2017;9:122.

23. Chantome A, Potier-Cartereau M, Clarysse L, Fromont G, MarionneauLambot S, Gueguinou M, et al. Pivotal role of the lipid raft SK3-Orai1 complex in human cancer cell migration and bone metastases. Cancer Res. 2013;73(15):4852-61.

24. Williams RT, Senior PV, Van Stekelenburg L, Layton JE, Smith PJ, Dziadek MA. Stromal interaction molecule 1 (STIM1), a transmembrane protein with growth suppressor activity, contains an extracellular SAM domain modified by N-linked glycosylation. Biochim Biophys Acta. 2002:1596(1):131-7.

25. Shuttleworth TJ, Thompson JL, Mignen O. STIM1 and the noncapacitative ARC channels. Cell Calcium. 2007:42(2):183-91.

26. Mignen O, Thompson JL, Shuttleworth TJ. STIM1 regulates Ca2+ entry via arachidonate-regulated Ca2+-selective (ARC) channels without store depletion or translocation to the plasma membrane. J Physiol. 2007;579(Pt 3):703-15.

27. Sabbioni S, Barbanti-Brodano G, Croce CM, Negrini M. GOK: a gene at 11 p15 involved in rhabdomyosarcoma and rhabdoid tumor development. Cancer Res. 1997:57(20):4493-7.

28. Oritani K, Kincade PW. Identification of stromal cell products that interact with pre-B cells. J Cell Biol. 1996;134(3):771-82

29. Jardin I, Lopez JJ, Redondo PC, Salido GM, Rosado JA. Store-operated Ca2+ entry is sensitive to the extracellular $\mathrm{Ca} 2+$ concentration through plasma membrane STIM1. Biochim Biophys Acta. 2009;1793(10):1614-22.

30. Cheng KT, Liu X, Ong HL, Swaim W, Ambudkar IS. Local ca(2)+ entry via Orai1 regulates plasma membrane recruitment of TRPC1 and controls cytosolic ca(2)+ signals required for specific cell functions. PLoS Biol. 2011; 9(3):e1001025.

31. Sabbioni S, Veronese A, Trubia M, Taramelli R, Barbanti-Brodano G, Croce $\mathrm{CM}$, et al. Exon structure and promoter identification of STIM1 (alias GOK), a human gene causing growth arrest of the human tumor cell lines G401 and RD. Cytogenet Cell Genet. 1999;86(3-4):214-8.

32. Zhang Z, Liu X, Feng B, Liu N, Wu Q, Han Y, et al. STIM1, a direct target of microRNA-185, promotes tumor metastasis and is associated with poor prognosis in colorectal cancer. Oncogene. 2015;34(37):4808-20.

33. Manji SS, Parker NJ, Williams RT, van Stekelenburg L, Pearson RB, Dziadek M, et al. STIM1: a novel phosphoprotein located at the cell surface. Biochim Biophys Acta. 2000;1481(1):147-55.

34. Bordron A, Bagacean C, Mohr A, Tempescul A, Bendaoud B, Deshayes S, et al. Resistance to complement activation, cell membrane hypersialylation and relapses in chronic lymphocytic leukemia patients treated with rituximab and chemotherapy. Oncotarget. 2018;9(60):31590-605.

35. Bagacean C, Zdrenghea M, Tempescul A, Cristea V, Renaudineau Y. Anti-CD20 monoclonal antibodies in chronic lymphocytic leukemia: from uncertainties to promises. Immunotherapy. 2016;8(5):569-81.

36. Hallek M. Chronic lymphocytic leukemia: 2017 update on diagnosis, risk stratification, and treatment. Am J Hematol. 2017:92(9):946-65.

Ready to submit your research? Choose BMC and benefit from:

- fast, convenient online submission

- thorough peer review by experienced researchers in your field

- rapid publication on acceptance

- support for research data, including large and complex data types

- gold Open Access which fosters wider collaboration and increased citations

- maximum visibility for your research: over $100 \mathrm{M}$ website views per year

At $\mathrm{BMC}$, research is always in progress.

Learn more biomedcentral.com/submissions 